\title{
BRITISH AND AUSTRIAN DOCUMENTS FOR THE POSITION OF THE MUSLIM POPULATION IN SALONICA AND ITS SURROUNDING AREA DURING THE BALKAN WARS
}

\author{
VERA GOSEVA, NATASHA KOTLAR-TRAYKOVA
}

\begin{abstract}
Vera Goseva, Natasha Kotlar-Traykova, British and Austrian documents for the position of the Muslim population in Salonica and its surrounding area during the Balkan Wars (Brytyjskie i austriackie dokumenty o sytuacji ludności muzułmańskiej z Salonik i okolic podczas wojen bałkańskich).
\end{abstract}

Balcanica Posnaniensia. Acta et studia, XIX, Poznań 2012, Wydawnictwo Instytutu Historii UAM, pp. 231-239, ISBN 978-83-63-047-17-7, ISSN 0239-4278. English text with a summary in Polish.

Vera Goseva, Natasha Kotlar-Traykova, Institute of National History - Skopje.

In this article we shall study the position of the second largest community in the city of Salonica - the Muslim community - during the Balkan Wars (1912-1913), using British and Austrian documents. ${ }^{1}$

Towards the end of the $19^{\text {th }}$ century and the beginning of the $20^{\text {th }}$ century, the city of Salonica was an important trading, cultural and social-political centre in the Ottoman state. It was a multicultural environment and, according to an 1890 statistical assessment, it had 118000 inhabitants. $^{2}$ Out of this number of inhabitants: 55000 were Jews; 26000 were Turks; 16000 were Greeks; 10000 were Bulgarians; 2500 were Romanies; and 8500 were of other ethnic affiliation. ${ }^{3}$

While the Balkan League was in the making, the city of Salonica was an important place in the political and military negotiations between the Kingdom of Greece and the Bulgarian Empire. Considering that an agreement was not reached, the is-

\footnotetext{
${ }^{1}$ The documents are from the State Archive of the Republic of the Macedonia (SARM) / Државен архив на Република Македонија (ДАРМ).

${ }^{2}$ К'нчов В., Избрани произведения, том втори, София 1970, 440.

${ }^{3} \mathrm{Ibid}, 440$. Expressed in percentage, it means that $46.6 \%$ were Jews; $22.03 \%$ were Turks and members of other ethnic communities who declared their religious affiliation to be Muslim; $13.6 \%$ were ethnic Greeks and members of other ethnic communities whose religious affiliation was with the Patriarchate of Constantinople, i.e. adherents of the patriarchate, $8.4 \%$ were Bulgarians and members of other ethnic communities whose religious affiliation was with the Bulgarian Exarchate, i.e. adherents of the exarchate.
} 
sue of who would get Salonica remained opened before the beginning of the Balkan Wars. ${ }^{4}$ Hence, even before the beginning of the Balkan Wars, both sides opted for a forced advance of their armies towards the city in the hope that they would thus conquer it and include it in their new state borders. The actual situation in the field indicated that the Greek army stood greater chances of realising that idea. After the victory of its forces near Sarantáporon, on the $23^{\text {rd }}$ October 1912, over the Turkish forces led by the city's military commander, Hassan Tahsin Pasha, the road for its advancement towards Salonica was clear. Negotiations for taking over the city began on the $7^{\text {th }}$ November, almost two weeks after the battle. The terms suggested by the Greek side were as follows: the Turkish forces were to lay down their weapons and to be interned in suitable locations, while the gendarmerie and the police were to keep their jobs until the Greek authorities replaced them. Contrary to the general expectations that the Turkish side would accept the terms, General Hassan Tahsin Pasha rejected them and strove to replace them with other terms. His attempt to gain time by prolonging the negotiations was unsuccessful because in the afternoon of the following day, on the $8^{\text {th }}$ November 1912 , the Greek forces entered the city without any substantial efforts.

Negotiations on the terms for surrendering the city were led on the night of the $8^{\text {th }}$ and $9^{\text {th }}$ November 1912 between the representatives of the Greek Crown Prince Constantine and Hassan Tahsin Pasha. The terms for the city's capitulation, which were almost identical to the ones previously offered, were signed at 6 o'clock that morning. According to them, the Turkish forces led by Hassan Tahsin Pasha were to lay down their weapons in military warehouses held by the Greek army, and the disarmed forces were to be interned in Zeitinlik and in Kara-Bouroum, as well as in other places where they would remain under Greek authority. It was envisaged for the disarmament to be carried out within 48 hours. The officers were allowed to keep their weapons and be provisionally treated as captives, while the city officials, the gendarmerie and the police were allowed to keep their weapons, their freedom, and to continue their duties until further notice. A large portion of these terms for capitulation were not carried out in accordance with the signed document which resulted in a number of reactions. ${ }^{5}$ Crown Prince Constantine was already in Salonica at 4 o'clock on the morning of $10^{\text {th }}$ November 1912, and the reason behind this haste was the speed with which the Bulgarian army was advancing towards the city. The desire of the Greek forces to establish their position as the sole conquerors of Salonica was realized. The

\footnotetext{
${ }^{4}$ Абаџиев Г., Балканските војни и Македонија, Скопје 1958, 46.

5 Државен Архив на Репубика Македонија, Скопје (ДАРМ). M-1966 (FO 371/1507/51111). A characteristic one was the problem with the Turkish military forces. Even though it was agreed that they would not be treated as prisoners, they were in fact guarded by the Greek army and some of them were even placed in the camps west of the city. (ДАРМ. M-1966 (FO 371/1508/53714)) For these reasons, on the $19^{\text {th }}$ November 1912, Hassan Tahsin Pasha sent a Memorandum to His Highness Prince Nicholas of Greece. In it, amongst other things, he objected to the "the acts and proceedings which have been and are being permitted in violation of the agreements signed between the two parties". (ДАРМ.M-1966 (FО $371 / 1507 / 51111)$ ).
} 
vanguard of the Bulgarian forces that entered the city on the morning of the $10^{\text {th }}$ November was received by Crown Prince Constantine who had already appointed a prefect (an administrator) for the city - P. A. Argyropoulos. ${ }^{6}$

But, according to the English Consul-General in Salonica, Harry H. Lamb, and the situation in the city became quite disturbing despite the establishment of Greek authority over it. ${ }^{78}$ The cause for that turbulence was the intensifying of the rivalry between the Greeks and the Bulgarians about who should have control over the city. The arrival of the King George ( $11^{\text {th }}$ November) was also aimed at strengthening the Greek rule over Salonica. He entering the city with an army of 20000 men coincided with the entrance of the Bulgarian Prince Boris escorted by 5000 Bulgarian soldiers (after Crown Prince Constantine gave him his consent).

Regarding the strengthening of the authority over the city, the instance involving the Bulgarian army which was reported by the British Consul-General H.H.Lamb is another characteristic example. He wrote the following: "On the $14{ }^{\text {th }}$ (November), the two parties twice nearly came to blows over the possession of the Mosque of St. Sophia (Hagia Sophia), over which the Bulgarians have hoisted their national (Bulgarian-our note) flag." 9

The number of soldiers from both armies and from their irregular units (comitajis and andartes) that were present in the city was constantly increasing, and so in the first days after the capitulation their numbers were almost identical. ${ }^{10}$ But their intolerance for one another reflected mostly in their treatment of the civilians. The British diplomat noted that the actions of both sides were audacious, conducting searches and robbing people and houses in and around the city. ${ }^{11}$ The Bulgarian army had displayed cruelty in its treatment of the civilian population, including the Muslim population, even as it was advancing towards Salonica. They would leave the places they had passed through for the "local comitajis" ${ }^{12}$ (irregular units) to administer, whose first step was to disarm all Muslims and give their weapons to the Christian population. Their next step was to rob the Muslim land owners, take the cattle, and plunder the wheat reserves, as well as to set on fire "everything that could not be taken along". ${ }^{13}$ According to Lamb, "The Mussulman notables in the towns were then forced to pay large sums for a few days respite, after which their houses were plundered and they only too often killed. (..) In many districts there is only too good rea-

\footnotetext{
${ }^{6}$ Former Prefect of Larisa.

7 Official notice of the occupation of Salonica by the Greek troops. (ДАРМ.M-1966 (FО $371 / 1507 / 50525)$

8 "The most disquieting feature in the present situation is the growing ill-feeling between the Greeks and Bulgarians.” ДАРМ.M-1966 (FO 371/1507/50526).; ДАРМ.M-1966 (FO 371/1507/50521).

9 ДАРМ.M-1966 (FO 371/1507/50526).

10 Ibidem. This trend continued and further so that in December 1912, that number was: 45,000 Greek soldiers and 40,000 Bulgarian soldiers. (ДАРМ.M-1966 (FO 371/1508/53714).

11 ДАРМ.М-1965 (FO 371/1507/ 50278).

12 ДАРМ.M-1966 (FO 371/1507/51709).

${ }^{13}$ Ibidem.
} 
son to believe that organised massacre has been resorted to." ${ }^{14}$ According to the same source, the village Jajladzik near Salonica was completely destroyed by the Bulgarian army (and the estate owned by Suleiman Pasha burned down). This event was also confirmed by the British member of the Carnegie commission H.N.Brailsford who reports, however, that it was committed by the "Greek army and the people from the nearby Greek villages". ${ }^{15}$

The British documents give accounts of Greek behaviour as well. The Greek authorities in the city of Salonica brutally violated the terms of the Protocol for Capitulation. A large number of Turkish officers who were, according to the Protocol, supposed to be provisionally treated as prisoners, were arrested and boarded on steamships for deportation to Turkish docks. Among the arrested were: Dr. Nazim Bey former Secretary General for the Committee of Union and Progress, and the Director of the Red Crescent hospital in Salonica, two former leaders of the political party from the city, as well as a number of gendarmerie officers and their commander. ${ }^{16}$

The situation in the city became even more critical because the number of its inhabitants doubled in size. The military operations in different parts of Macedonia resulted in large numbers of refugees, mostly Muslims, arriving in the city from those territories from which the Ottoman army was withdrawing. So, according to the report by the British Consul dated the $26^{\text {th }}$ October 1912, more than 5000 civilian refugees arrived in Salonica from the interior of the country. ${ }^{17}$ Already the following day, the same source reported that their number was $10000,{ }^{18}$ on the $1^{\text {st }}$ November it was $40000,{ }^{19}$ and that it was 50000 on the $16^{\text {th }}$ December. ${ }^{20}$

Salonica, as an important urban and administrative centre in the Ottoman state, was deemed by the civilian population, and especially by the Muslim population, a safe harbour from the military actions of the Balkan allied forces. The numerous demoralised and defeated Ottoman soldiers were of a similar opinion as well. ${ }^{21}$ To them, the city was a place where they could rest and get food, ${ }^{22}$ which is why their numbers

${ }^{14}$ Ibid.

15 Поранешните Балкански Војни (1912-1913). Извештај на Карнегиевата балканска комисија, Скопје 2000, 327.

16 The Greek authorities justified this particular action with the excuse that an uprising of the Muslim population had been in preparation. (ДАРМ.M-1966 (FO 371/1507/51709)).

${ }^{17}$ Ibidem.

18 ДАРМ.М-1965 (FO 371/1505/47817).

19 ДАРМ.M-1965 (FO 371/1506/48282).

20 ДАРМ.М-1966 (FO 371/1508/53714).

21 ДАРМ.M-1965 (FO 371/1506/48282). (Acording Consul-General Lamb report from 7 th November: "During these two days deserters from Hassan Tahsin's force poured in an almost continuous stream into Salonica, where they were mostly collected and sent back, after refitting, to the front. They took no pains to conceal either their unwillingness to continue the war, their complete indifference to its results, or their supreme contempt for the greater number of their officers. Their only idea seemed to be to get into Salonica, where they looked forward to receiving food and a night's rest. Many declared that they had been three or even four days without bread, and it is officially admitted that the commissariat arrangements of a whole division broke down for forty-eight hours.")

22 ДАРМ.М-1965 (FO 371/1506/48964). 
reached "30000 or 40000" towards the end of October $1912 .{ }^{23}$ That was what the situation was like until the Protocol for Capitulation was signed, at which time 25000 Turkish soldiers from the city surrendered.

In the first few weeks of the Balkan Wars, the Muslim population became the object of different kinds of retaliatory and criminal actions committed by their Christian fellow citizens and the Balkan allied forces, because of which they were forced to flee. That was the reason why the number of the population in Salonica was constantly increasing. From a city of 150000 inhabitants, it became a city of twice as much population (310000). ${ }^{24}$

The refugees who fled to the city were housed in the city's mosques, churches, and in the vacant buildings; however, many of them, women and children included, were forced to spend the nights out in the open and in cold weather. ${ }^{25} \mathrm{Up}$ until the capitulation of Salonica, the food for the refugees (bread only) was provided by the city's mayor - Osman Sait Bey. After the arrival of the Greek and the Bulgarian armies in the city, the situation concerning the food for the refugees deteriorated dramatically. Many of the Muslim refugees died of starvation. In an attempt to alleviate this grave situation, French Sisters of Mercy were also engaged and they were providing the refugees with all the food they could spare. But despite all that, the state that the starved refugees were in was so desperate that they would even take the leftovers from the military ships docked in the harbour.

It was difficult to establish "any settled form of government" in the city, and so the cases involving thefts and other kinds of violence committed by members of the two allied armies went without punishment. ${ }^{26}$ This was particularly characteristic for the first few weeks after the capitulation of Salonica. The British diplomatic reports registered a number of such cases. Not even the more important representatives of the Ottoman authorities in the city, such as Hassan Tahsin Pasha and the mayor at the time, Osman Sait Bey (who remained at that position in the period from 1912 to 1916, and again from 1920 to 1922), were exempt from being robbed. Thus, in the family house of Hassan Tahsin Pasha, his son and his nephew were robbed under the pretext that they were in possession of weapons without permission. Bulgarian soldiers entered the house of Osman Sait Bey by force and, using their bayonets, made him hand over all the money that was in the house, his wife's jewellery, and the numerous rare art objects. ${ }^{27}$ There are also documents containing information about Greek soldiers whose conduct was unbecoming. A characteristic example of such conduct unbecoming is the case when a Turkish officer was mistreated on one of the main streets of the city in broad daylight. His head was shaved, and he was covered in mud from head

23 ДАРМ.М-1965 (FO 371/1506/48282).

24 ДАРМ.М-1966 (FO 371/1508/ 53714).

25 Ibidem.

26 ДАРМ.М-1966 (FO 371/1507/51709). On the $13^{\text {th }}$ November, the Minister of Justice, V.Ractivan, was appointed by royal edict an administrator of those regions in Macedonia occupied by Greek forces. Prince Nicholas was appointed a military governor of Salonica (ДАРM.M-1966 (FO371/1507/50525).

27 ДАРМ.М-1966 (FO 371/1507/50521). 
to toe and robbed - his money and his watch were taken from him. With the intent to humiliate the religious and national feelings of the Muslim population, the Greek soldiers would mistreat anyone wearing a fez. ${ }^{28}$

Not even the members of other nationalities living in the city, foreign nationals included, were spared the unpleasant incidents and troublesome episodes. ${ }^{29}$

In the surrounding area of the city, the position of the Muslim population was much worse. There were numerous instances where entire Muslim villages were burned to the ground, as well as instances of people being murdered, raped, and robbed. There is a report along those lines by the Carnegie commission which contains references regarding crimes committed by the Bulgarian paramilitary units in the villages of Rayanovo, Planitca and Kukurtovo. It contains vivid descriptions of how people (men, women and children) were executed..$^{30}$ This episode was also confirmed by the diplomatic representatives of other European countries. ${ }^{31}$

The said lawlessness was due to the fact that the local authority in the settlements around Salonica was largely left in the "hands of notorious bandits." ${ }^{22}$ Because of that, it is not surprising that the Muslim population requested the establishment of an international commission that would investigate and bring to light the numerous crimes. ${ }^{33}$ This initiative got only the attention of the Austrian and the German consuls in Salonica ${ }^{34}$, but it was never brought to existence. ${ }^{35}$ The request submitted by Cheri Pasha, a member of the Red Cross mission, dated the $2^{\text {nd }}$ December 1912 and addressed to the British Government, demanding protection for the Muslim population from the destructive actions carried out by the allied military units, shared the same fate. ${ }^{36}$

The establishment of a new administrative authority was a slow and difficult process. In some cases, the process itself took six whole weeks after the elimination of the Ottoman rule. ${ }^{37}$

The numerous cases of violence, troublesome incidents and uncertainty had the effect of many Muslim refugees leaving for Izmir and Istanbul via Salonica. ${ }^{38}$ The signing of the Peace Treaty of Bucharest (10 ${ }^{\text {th }}$ August 1913) meant continuance of the emigration process of the population from Thrace and Macedonia, including Salonica and its surrounding area. What is characteristic for this emigration wave is that it involved

28 Ibidem.; Мазовер М., Солун град на духови. Христијани, Муслимани и Евреи 1430-1950, Скопје 2008, 285.

29 ДАРМ.M-1966 (FO 371/1507/53264). Such were the instances involving an Italian citizen, the Consul of Persia, etc.

30 Поранешните Балкански Војни, 104.

31 Ibid, 106.

32 ДАРМ.M-1966 (FO 371/1507/50695).

33 Ibidem.

34 ДАРМ.M-1966 (FO 371/1507/52380).

35 Поранешните Балкански Војни, 12.

36 ДАРМ.М- 1966 (FO 371/1507/51479).

37 Поранешните Балкански Војни, 104.

38 Мазовер М., Солун град на духови, 283. 
large numbers of Christian, Jewish and Muslim population. According to Austrian diplomatic reports, the number of emigrants in Salonica and its surrounding area after the end of the Second Balkan War was 140000, of which "at least half of them are Muslims" ${ }^{39}$ Almost all of them preferred going to territories under Ottoman rule. A special "Muslim Transport Committee" ${ }^{40}$ was established, which organised the transfer of refugees to Asia Minor. This emigration acquired such large proportions that the Turkish Minister of Internal Affairs, Mehmed Taalad Pasha (1913-1917) sent a message to the Salonica mufti informing him that: " authorities of Smyrna will no longer allow anchoring of any further ships with immigrants", and as justification for such an action he pointed out that the Vilayet of Aydin had already received 75000 refugees and that the hygienic conditions there were failing; the refugees " now are diverted to Constantinople, Mudania (Bursa), and most of them to Mershina, Aleksandreta, Antakya." ${ }^{41}$ The chronicler of Salonica, Mazover, states that Mustafa Kemal's mother, sister and his cousin were among the refugees who fled to the refugee camps in Istanbul. The last governor of Salonica, Nazim Pasha, shared the same fate, too. ${ }^{42}$

Having in mind the above presented, it can be concluded that the Balkan Wars had a dramatic effect on the position of various ethnic and religious groups on the Balkans and, in this particular case, on the Muslim ethnic group. What characterised these wars was the cruelty exhibited towards the civilian population which manifested in a great loss of human life, systematic extermination of the population belonging to the opposite side, a large number of annihilated villages, and the destruction of entire regions. An immense demographic change took place over a short time interval, creating new political, economic, and cultural conditions in the Balkans. As regards Salonica in particular, the census carried out in 1913 by the Greek government registered the following data: the total number of the city's population was 157889 inhabitants, of which close to 40000 were registered as Greeks (or 25.3\%), 45867 were registered as "Ottomans" (people of Muslim affiliation, but who were also Ottoman citizens), 61439 as Jews ${ }^{43}$ and others. A year later, in May 1914, the German Consul in

39 ДАРМ. Министерство за надворешни работи-АвстроУнгарија (понатаму: МНР-АУ). М-316 (XV/177/34-38) On the 12 $2^{\text {th }}$ September 1913, the Austrian Consul in Salonica informed his superior about the following: "The emigration of Muslims should not be seen as a consequence of the Second Balkan War and is undiminished in those areas that, in accordance with the Peace Treaty of Bucharest, remained under Bulgaria. It has undoubtedly gotten a new sudden stimulus, but it has been present since the beginning of the First Balkan War, as Your Excellence has already been informed. (..) The Muslim Committee has been making assessments of it since the end of October, i.e. since the strike on Kumanovo; maybe the assessment is too high - that it is about 100,000 , and the Committee believes that in the coming period it shall increase (twofold) in size."

40 ДАРМ.МНР-АУ.М-316 (XV/177/31-33).

41 ДАРМ.МНР-AУ.M-316 (XV/177/34-38); As regards the size of the emigration wave, with respect to the city of Izmir in particular, the fact that in 1800 it had a population of 150,000 inhabitants, while in 1914 that number increased to 300,000, speaks volumes in itself. (Quataert D., The Ottoman Empire, 1700-1922, Cambrigde 2000, 114.)

42 Мазовер М., Солун град на духови, 285.

${ }^{43}$ Ibid, 257. 
Salonica noted the following: "Salonica will probably soon change its Judeo-Turkish appearance. The Greek language is heard a lot more than it used to, and it seems that everyone is trying to learn this official language. King Constantine says that he had been going over the submitted plans for redecorating for some time and asserts that they shall be carried out soon in order for the city to lose its Turkish appearance." ${ }^{\prime 44}$

In short, we can conclude that the Balkan Wars satisfied the ambitions of the Balkan states' nationalist circles which, of course, had the politics of the Great Powers behind them. That such of the case was obvious at both conferences that took place in London at the same time - the Conference of the Ambassadors of the Great Powers and the Peace Conference of the Balkan states engaged in war. 80 years after these wars, a new war threatened the Balkans and was led, with all its attributes of cruelty, on the territory of former Yugoslavia. Reflecting on this phenomenon from today's perspective, we can come to the conclusion that the historical lesson taught by the Balkan Wars (1912/13) had not been learnt.

\section{Bibligraphy}

Абаџиев Г., Балканските војни и Македонија, Скопје 1958.

Erickson E., Defeat in Detail: The Ottoman Army in the Balkans, 1912-1913, Westport 2003.

К'нчов В., Избрани произведения, том втори, София 1970.

Мазовер М., Солун град на духови. Христијани, Муслимани и Евреи 1430-1950, Скопје 2008.

Поранешните Балкански Војни (1912-1913). Извештај на Карнегиевата балканска комисија, Скопје 2000.

Hall R., The Balkan Wars 1912-1913. Prelude to the First World War, London and New York 2000.

Quataert D., The Ottoman Empire, 1700-1922, Cambrigde 2000, 114.

Штепан Х.Л., Македонскиот јазол, Идентитетот на Македониите прикажан на примерот на Балканскиот сојуз (1878-1914), Скопје 2005.

44 Штепан Х.Л., Македонскиот јазол, Идентитетот на Македониците прикажан на примерот на Балканскиот сојуз (1878-1914), Скопје, 2005, 357. 


\title{
BRYTYJSKIE I AUSTRIACKIE DOKUMENTY O SYTUACJI LUDNOŚCI MUZUŁMAŃSKIEJ Z SALONIK I OKOLIC PODCZAS WOJEN BAŁKAŃSKICH
}

\begin{abstract}
Streszczenie
Zasadniczym celem niniejszej rozprawy jest przestudiowanie pozycji społeczności muzułmańskiej, drugiej co do wielkości w mieście Saloniki i jego okolicach, podczas wojen bałkańskich (1912-13) na podstawie brytyjskich i austriackich dokumentów zgromadzonych w Archiwum Państwowym Republiki Macedonii (ASRM).

Wojny o których mowa wywarły dramatyczny wpływ na pozycję wielu bałkańskich grup etnicznych i religijnych, a w tym konkretnym przypadku na społeczność muzułmańską. Cechą charakterystyczną działań zbrojnych było okrucieństwo okazywane ludności cywilnej, skutkujące zagładą niezliczonych istnień ludzkich, systematyczną eksterminacją ludności identyfikowanej z przeciwną stroną konfliktu, znaczną liczbą osad dosłownie zmiecionych z powierzchni ziemi i dewastacją całych regionów. W krótkim czasie doszło do poważnych zmian demograficznych, w następstwie których na Bałkanach ukształtowały się zupełnie nowe warunki polityczne, ekonomiczne i kulturowe.

Wojny bałkańskie realizowały ambicje kręgów nacjonalistycznych z państw bałkańskich, wspieranych przez politykę mocarstw. Ten stan rzeczy był oczywistością podczas dwóch konferencji w Londynie (1912/1913), Konferencji Ambasadorów mocarstw i konferencji pokojowej dla państw zaangażowanych w konflikt militarny.
\end{abstract}


